УДК $81-27$

DOI: $10.17516 / 1997-1370-0474$

\title{
The Communicative Norm in Russian Informal Verbal Communication: The Specificity of Child Speech
}

\section{Anastasiia B. Silvestrova*}

Krasnoyarsk State Pedagogical University named after V.P. Astafiev

89 Ada Lebedeva Str., Krasnoyarsk, 660049, Russia

Received 03.07.2019, received in revised form 06.09.2019, accepted 20.09.2019

The article is devoted to the analysis of the communicative norm and disorders in informal Russian verbal communication on the basis of children's speech in conversations between children, children and parents, teenagers. Such parameters of communication as rules of speech behaviour for the convenience of the recipient and etiquette genres are considered based on a material of authentic children's statements published on the Krasnoyarsk Internet forum "Krasmama" and in the modern Russian literature for children. The article also considers a mechanism of communicative errors. Communicative scenarios of compliance and violation of the rules of speech behaviour are reconstructed. Particular attention is paid to statements having the purpose to manipulate the recipient. As a result, it was found that unconscious violations of communicative norms and, in particular, the rules of speech behaviour in the interests of a listener are characteristic of children's speech. The cause of errors may be the imitation of adult informal, reduced speech. On the other hand, following the communicative norm, namely observance of the rules of speech behaviour and the use of etiquette speech genres in child-parent communication leads to ambiguous results and may indicate a conscious intention of a child to influence or manipulate an adult. Etiquette statements coming out of a child's mouth are markers of adult speech. In communication between children, and especially between adolescents, as shown by the analysis of texts of modern literature for children, inappropriate compliance with etiquette standards may signalize the author's hidden goals that are still unknown to the addressee (influence, manipulation), or a communicative error.

Keywords: verbal communications, informal communication, communicative norm, communicative violation, communicative error, rules of speech behaviour, etiquette genres, politeness, child speech.

Research area: Russian language.

Citation: Silvestrova, A.B. (2019). The communicative norm in Russian informal verbal communication: the specificity of child speech. J. Sib. Fed. Univ. Humanit. Soc. Sci. DOI: $10.17516 / 1997-1370-0474$.

(C) Siberian Federal University. All rights reserved

* Corresponding author E-mail address: a-lia-nor@mail.ru 
Introduction. Modern ontolinguistics that explores the process of mastering speech by a child is closely connected with communication research, pragmatics, speech science, theory of speech genres and other related disciplines. Obviously, linguistic and sociocultural adaptation is impossible without an understanding of the regularities of communication. Mastering typical speech models and genres relevant in various communicative situations, ability to choose from a variety of linguistic means necessary to express one's own intentions and respond adequately to the interlocutor's replicas are not a complete list of the components of communicative competence.

The above said necessitates the analysis of a universal model of communication with the subsequent study of its specific implementations in "live" Russian speech, oral communication. Bearing in mind the conditional model of the communicative situation, we will focus on the parameters that are most significant for the present study, the neglect of which may affect the course and communication outcome. These parameters are:

- role relations of the participants of communication - an author and an addressee;

- register of communication;

- time and place of communication;

- rules of speech behaviour as a set of instructions for effective communication.

If the first three elements that make up the communicative situation do not need comments, the rules of verbal behaviour require clarification.

The concept of the Code of Speech Behaviour and its constituent rules was introduced into the scientific circulation by T.V. Shmeleva in the article "The Code of Speech Behaviour", published in 1983 in the journal "Russian Language Abroad" (Shmeleva, 1983). Although studies by T.V. Shmeleva turned out to be ideologically close to the Anglo-American theory of postulates and maxims of conversation associated with the names of D. Gordon and J. Lakoff
(Gordon, Lakoff, 1975), H.P. Grice (Grice, 1975) and G.N. Leech (Leech, 1983), yet the works of a Russian scientist are independent, original, and reflect the regularities of Russianlanguage communication. Developing the ideas of Iu.V. Rozhdestvenskii who studied the rules of speech behaviour on the material of paroemias (Rozhdestvenskii, 1979), T.V. Shmeleva formulated a recommendatory Code of Speech Behaviour out of 13 prescriptions and prohibitions on the basis of the analysis of modal categories of monologue texts. These rules are divided into three groups: 1) in the interests of a listener; 2) in the interests of a speaker; 3) requirements for the choice of language tools.

In general, the Code of Speech Behaviour is focused on an addressee of a message, since the most important factor for effective communication is compliance with the prescriptions and prohibitions, which presupposes that the addressee "should firstly be offered information corresponding to his requests and capabilities, and secondly, not inflicted any kind of communicative damage or resentment" (Shmeleva, 1983: 75). Thus, the priority is the psychological comfort of the listener. The speaker, if he is interested in successful communication, must take into account the addressee's role and personality characteristics: his age, gender, social status and communicative role in the dialogue, and also relate all these parameters to his own.

On the one hand, a native speaker learns the rules of speech behaviour intuitively and uses them unconsciously, thus adjusting his everyday speech behaviour with their help. It is proved by the fact that the rules of speech behaviour are quite successfully reconstructed from paroemias, proverbs and sayings that reflect the naive view of speakers of a given national language on correct speech (Rozhdestvenskii, 1979; Speranskaia, 1999).

On the other hand, the Code is not equal to speech etiquette and norms of the literary language. In everyday-life, informal speech, 
a violation of the literary norm and the use of, for example, jargon or vernacular will not be an obstacle to successful communication, if such usage is consistent with the nominative habits of the interlocutors.

The Code of Speech Behaviour is not identical to the postulates and maxims of speech communication and is governed not so much by the principle of politeness, as by the category of relevance in a particular communication situation. Therefore, the principle of communicative expediency that was singled out by V.G. Kostomarov and A.A. Leont'ev as one of the criteria of the literary language norm is extremely significant for the analysis of the rules of speech behaviour (Kostomarov, Leont'ev, 1966).

It is also important to take into account that the rules of speech behaviour are implemented in a dialogue based on various communicative scenarios. The article by E.V. Osetrova and Zhang $\mathrm{Bo}$, on the basis of the analysis of Russianlanguage correspondence in social networks, described such typical modes of implementation of communicative rules (more widely norms), as their "observance", "violation", as well as verbally expressed "prevention" as a way to prevent or mitigate a conflict (Osetrova, Zhang Bo, 2015). Let us also add to this list the mode of "exaggeration" as an exaggerated, excessive observance of the norm, which, as the analysis of texts shows, has an ambiguous effect on the outcome of communication.

Bearing in mind the above communicative scenarios and being limited by the present study of the children's, adolescent and parent-child dialogue in relation to the conditional equality of an author and an addressee, we focused on the functioning of the following rules of speech behaviour relevant to us in the interests of a listener:

- communicate information that does not differ from the logic of a listener and his ideas about the usual course of events;

- do not communicate information unpleasant for an interlocutor;
- as well as prescriptions relating to the choice of linguistic means by a speaker:

- speak according to the norm and as is customary;

- choose nominations in accordance with nominative habits: a) of your own, b) of a listener and c) in accordance with the subject of speech.

Material for the research. The research material included:

a) texts of modern children's literature as a source that made it possible to reveal the most expressive characteristics of a dialogue with the participation of children/teenagers, exaggerated by the writers precisely because of their typicality for modern Russian-language communication.

Russian children's literature contains rich material of authentic texts reflecting the current state of Russian speech. For the present study, in the light of the methodology for Russian as a Second Language, both regulatory dialogues corresponding to the standards of communication and etiquette, and examples of communicative violations committed by interlocutors unconsciously or purposefully are relevant. The study of this "negative" language material is extremely important for a more convex designation of the communicative norm itself.

b) transcripts of authentic dialogues of children and parents recorded during 2013-2016 on the Krasnoyarsk Internet forum "Krasmama" under the section "Children Are Talking" (https://forum.krasmama.ru/ topic/254988/ - access date 01/29/2019). The examples given in this article have been recorded and published by mothers who have noted the unusualness of children's statements, either deviating from communicative norms, or copying "adult" communicative tactics. Both of these options for the development of a communicative situation cause a comic effect and make it possible to analyse it more deeply on the basis of pronounced deviation from the norm. 
Results. In the course of the study of children's and adolescent communication, it was found that a) compliance with the Code of Speech Behaviour does not always guarantee a favourable outcome of communication, and b) violation of the rules does not always lead to disastrous consequences for communication.

This is explained by the specifics of a children's dialogue, in which an author and an addressee are equal in age and social status. Communication takes place in an informal setting, at the household level, therefore the observance of communicative norms is not necessary. Deviations from the Code of Speech Behaviour are often allowed without disastrous consequences for communication, since compliance with the principle of cooperation is a priority.

The modern child-parent dialogue seems to be practically free from formal requirements. Despite the obvious difference in age and role-playing status, in conversation with their parents, children do not feel limited in the choice of language means, using vernacular and even vulgar words in speech without negative consequences. For example:

[08.26.2015, the appeal of the daughter to the father]

D: Dad! It's your fault! Spread out your flippers here!

Or:

[08.27.2016, Grandson addresses his grandmother]

Grandson: Gram, you have a belly like an ogre!

Or:

[02.16.2014, mother talking to a daughter]

D: How are the children born?

M: In the hospital, a doctor cuts the abdomen and takes it out.

D: Why didn't you go whack?

The speech ontogeny of a child is based on the repetition and imitation of the speech of adults. As noted by ontolinguists, "the mastering of speech and the development of speech skills also implies the adoption of someone else's language experience and the reproduction of fragments of someone else's speech in their own statements" (Osokina, 2018: 89). Children, not owning all the functional styles of Russian speech due to their age and not distinguishing between the stylistic nuances of certain nominations, violate the communicative rules unconsciously. The tolerance of adults to communication disorders is due to the informal nature of communication, closeness of the interlocutors, as well as the slangy style of communication familiar to elders. Children's communicative errors are not perceived by adults as a reason for punishment, but rather they provoke laughter and tenderness. This tolerance is demonstrated by positive parental reactions to the stylistic and speech shortcomings in children's speech: "I was in stitches [laughing]," "my husband was in shock [a graphic symbol of a smile]", "my husband and I laughed."

Normative statements obviously prevail in children's speech, but, as the analysis of examples shows, they do not always have an unambiguous function. Politeness is a social norm that adults bring up in a child, so etiquette genres in a child's speech become peculiar markers of "alien", adult speech.

At first glance, the situation of compliance with communicative norms, which does not contain any violations, is the most favourable for the interlocutors. Its communicative scenario is as follows: observance of the communicative norms (with possible prevention of violation) by a speaker is continuation and a favourable outcome of communication.

Let us provide an example of such a dialogue from modern children's poetry. Here, the mode of exaggerated observance of the norm is implemented, namely the instructions "to speak according to the norm and as is customary":
- Hanging on a hook
Is an unpleasant custom:
I could be a prey for you
Thanks, - 
A worm bowed to a trout, -

Thank you for

not eating me!

- You are welcome, -

The fish answered modestly, -

And let me

Thank you too!

(Iasnov, 2003: 29)

Obviously, it is both an ironic and didactic poem called "A very polite conversation" designed to teach children the rules of etiquette and is consistent with the "adult" communicative norm. A child is aware of the importance of observing the rules of speech behaviour and the use of etiquette, phatic genres in certain communicative situations and can directly affect adults or manipulate them, deliberately raising a register of the communicative situation. In the following example, a son deliberately disarms his father with an unusual reaction, responding to a coarse threat with an etiquettical statement, thus returning the communication to the normative direction.

$[05 / 19 / 2015$, a son's reaction to a father's threat; spelling has been left unedited]

$F$ : Do you want me to spank you?

$S:$ No, thanks!

In addition, the child, recognizing the importance of politeness, can appropriate adult communicative tactics and play an atypical role for himself as a teacher of impolite adults, making them observe the rituals, as in the following example:

[01/10/2015, a boy makes a remark to a close relative who left the table without saying thank you]

\section{A boy: Where is "thank you?!"}

A similar mechanism also operates in the relations of inequality between an author and an addressee, namely, in a child's conversation with an unfamiliar adult, when the youngest participant in the age and status of communication tries to rise to the level of his interlocutor, adopts adult communicative tactics, and plays an atypical role for himself.
Let us compare the following fragments:

[dialogue between a child and an adult situation of making acquaintance]

[violation of instructions to adults to speak in accordance with the norm and as is customary and to act in accordance with the ideas about the usual course of events; negative reaction of a child]

- Do you trust an apartment key to any stranger?

[adjustment of speech behaviour by an adult, the return of the communicative situation in the formal register]

- Oh, please, forgive me, - a man offered his hand, - Let's get acquainted! Molchanov Valerii Alekseevich, an engineer.

[acceptance of an apology by the addressee, agreement to continue communication in the mode of exaggerated compliance with the norm]

- Valerii Snegirev, a student of the sixth " $B$ ", - Valerka answered with dignity.

[favourablecontinuation of communication, the implementation of the etiquette speech genre of "making acquaintance"]

- Nice to meet you!

(Georgiev, 2012: 142)

Or:

[polylog between children and adults situation of making acquaintance]

A French peace advocate was drinking tea with Tula honey-cakes. Beautiful Ira, as if from a Russian folk tale, was looking at him.

[exaggerated observance of communicative norms]

- You should get acquainted, - it wasn't even her speaking, she literally started singing.

- Here, Henri, this is my nephew Egor, and this is his friend Ksiusha.

The peace advocate affectionately smiled at Soviet children.

[children's consent to continue communication in the formal register]

- Hello, - we said politely, - We came only

for a minute, we are having a rehearsal."

(Dragunskaia, 2012: 30-31) 
Thus, the observance of the rules of speech behaviour in the interests of a listener, and especially the use of etiquette speech genres in children's speech, serves as a marker of adult communication. A child consciously resorts to the normative speech behaviour in the event when an adult deviates from the norm. Then the child adopts adult communicative tactics and translates communication from etiquette genres into a neutral or formal register, depending on the degree of closeness with the adult.

A scenario of the etiquette communicative model in a children's and especially adolescent dialogue differs from that discussed above and is implemented differently: the speaker's observance of the generally accepted norm without taking into account the corporate child/adolescent norm - a listener's explicit negative reaction - difficulty or termination of communication.

It is important to note that this etiquette model is so atypical for children's speech that in the text it usually either signalizes the speaker's communicative error or indicates a deliberate violation of the corporate norm in order to manipulate or directly affect the interlocutor.

The analysis of texts implementing the etiquette communicative model in children's communication allowed us to create the following typology of communicative disorders:

a) a communicative error as an unconscious violation of the situational norm, which was not intended to cause communicative damage or insult to the addressee; depending on the degree of closeness of the participants of communication, it can have various consequences: provoke a communicative failure that is easily amenable to correction, or a communicative failure, a categorical refusal of the addressee to continue communication

b) manipulation characteristic of friendship; the author realizes it consciously intending to provoke or coerce the addressee to perform certain actions; the manipulative tactic is perceived by the addressee with caution, to the extent of ascertaining the true intentions of the author;

c) in some cases, manipulation goes into a direct impact on the addressee and can provoke an extremely conflict situation.

Let us refer to the examples of the implementation of each of the above scenarios.

A) Let us consider an example of erroneous compliance with the rules of etiquette:

[dialogue of a teenage girl and a younger boy]

[Adherence to the etiquette norm, despite the nominative habits of the addressee, a speech genre of the compliment]

Los'ka suddenly said:

- Zhenia, you are beautiful today.

[Astonishment, bewilderment as the reaction of the addressee]

I almost snipped my finger with a knife.

- Well, Los'! That's a good one!

(Krapivin, 2006: 311)

Violating the corporate children's standard to follow an informal, rough style of communication, the boy unknowingly and out of good motives makes a mistake that complicates communication significantly. The reason for causing the listener communicative damage lies in the violation of the instruction to choose nominations in accordance with its nominative habits and ideas about the usual course of events. In this dialogue, the error, however, is amenable to correction, and communication continues favourably beyond the fragment.

B) The implementation of an "adult" etiquette model in children's communication inevitably complicates it, puts the addressee in an awkward position, forcing him to analyse the reasons for the author's speech behaviour, to search for hidden meanings, and to reveal the true intentions of the speaker. Thus, the natural course of communication is suspended, which allows us to speak about a communicative violation.

Formally observing the norms of politeness, an author can manipulate an addressee and provoke him to the needed actions, using the rules of speech behaviour and etiquette speech 
genres as tools. A child-addressee, in turn, is aware of atypicality, even suspiciousness of such tactics, precisely due to the fact that in the children's informal environment, the compliance with the Code of Speech Behaviour is perceived as a deviation from the corporate norm.

In the following situation, an addressee (a girl) is perplexed precisely because an author (a boy) refuses the usual aggressive tactics, actively observing the norms of communication. This is explained by the true purpose of the author: a verbose, polite greeting is essentially a means of manipulation:

[a dialogue between peers]

[implementation of etiquette and phatic speech genres uncharacteristic for children's communication]

- Hello! You went to gather strawberries? Well done. How are you doing? Does your throat hurt?

[bewilderment of the addressee; restrained reaction]

He is not teasing or calling names... What a surprise!

- No, the throat does not hurt.

[reveal of the true intentions of the speaker, direct impact in the form of the imperative mood and manipulation]

- Let's go then $<\ldots>$

"Come on, scream, since your throat does not hurt," Kostya orders. - Or you're afraid?

- ZYKINA IS A GOOSE!!! - I am screaming the loudest with delight.

(Dragunskaia, 2012: 128)

Let us also consider the example of a polylogue with external observance of communicative norms, with the aim of manipulation, even aggressive impact and physical violence.

[a polylogue between a teenager and a group of hooligans]

[An exaggerated joyful greeting with an obvious discrepancy to the actual course of events: communicants do not know each other]

- Oh, my friend, we have not seen each other for a long time! - The youngest boy said. < .. >
[Culmination of the ritual: clarification of Bucha's true communicative intentions]

- He has no time! - The one who was called Bucha sobbed. - He came here just to return his dept...

[Confirmation of the addressee's suspicions about the hostility of the situation and the intentions of the author]

- What dept? - Vital'ka grew suspicious.

[Aggressive impact on the addressee, which is externally expressed in compliance with speech standards]

- For ice cream! - Bucha reminded him smiling. - Remember, I treated you to ice cream? Walnut sundae? Return my money! < .. >

(Georgiev, 2012: 77-78)

Throughout the entire polylogue the hooligans provoke Vital'ka into explicit speech aggression by means of the untypical and irrelevant speech tactics of deliberate benevolence.

The boy is trying to understand the intentions of strangers, but he cannot guess their true goals by external signs (the guys looked good-natured; ... the guys looked peacefully). Nevertheless, Vital'ka behaves cautiously, because he notices how hooligans limit his physical freedom and ignore his attempts to end their conversation: firstly, polite ones (Guys, I'm in a hurry), and then persistently aggressive ones (Let me go!).

The ritual impact on the addressee reaches its climax at the moment when the listener is forced to use verbal aggression and thereby provoke the originally planned conflict. Although the fight begins suddenly (He suddenly hit Vital'ka on the chin), the signal for its beginning is given verbally (Bucha, as if waiting for these words, immediately "could not resist it").

Explicit speech aggression, as we noted above, is usually perceived by a teenager as something habitual and corresponding to his nominative habits. Excessive politeness and ceremoniousness of the conversation may imply the author's hostile intentions in the eyes of the addressee, so in such cases the listener expects a trick or trouble. 
In the analysed example, the hooligans who initiated the ritual and the conflict that followed it consciously choose the tactics of speech impact on the addressee and therefore are initially in a better position. The addressee is forced to act in accordance with the ritual rules imposed on him and cannot either change the course of the communication or leave it.

Conclusion. Let us sum up the research.

1. Children's speech is characterized by unconscious violations of communicative norms and, in particular, the rules of speech behaviour in the interests of a listener. The cause of errors can be the imitation of adult informal, often familiar, reduced speech. In the process of speech ontogenesis, a child only learns to distinguish between the stylistic norms of word usage and can use colloquial, vulgar, rude words without the intention to offend an interlocutor. Parents, as a rule, realize the inevitability of these errors and consider them permissible. Marking these children's statements as non-normative, adults treat them tolerantly and react positively.
2. Adherence to the communicative norm, namely observance of the rules of speech behaviour in the interests of the listener and the use of etiquette speech genres in child-parent communication leads to ambiguous results and may indicate a conscious intention of a child to influence or manipulate an adult. Etiquette statements coming out of the mouth of a child are markers of adult speech. The importance of polite utterances is realized by children, first of all, at the level of the rituals of greeting, making acquaintance and appreciation. The child seeks to observe the ritual and raises the register of communication to the formal one in the event when an adult violates the communicative norms.

3. In communication between children, and especially between adolescents, as evidenced by the texts of modern children's literature, inappropriate adherence to etiquette standards may signalize the author's hidden goals that are still unknown to the addressee (influence, manipulation), or a communicative error.

\section{References}

Dragunskaia, K.V. (2012). Muzhskoe vospitanie [Male education]. Moscow, Zhuk. 232 p.

Georgiev, S.G. (2012). Sobaki ne oshibaiutsia [Dogs are not wrong]. Moscow, Zhuk. 185 p.

Gordon, D., Lakoff, G. (1975). Conversational Postulates. In Syntax and semantics, 3, 83-106.

Grice, H.P. (1975). Logic and conversation. In Syntax and semantics, 3, 41-58.

Iasnov, M.D. (2013). Den'otkrytykh zverei: stikhi [Animals open day: poems]. SPb. 48 p

Kostomarov, V.G. (2014). Iazyk tekushchego momenta: poniatie pravil'nosti [The language of the moment: the concept of correctness]. SPb. 220 p.

Kostomarov, V.G., Leont'ev, A.A. (1966). Nekotorye teoreticheskie voprosy kul'tury rechi [Some of the theoretical issues of speech culture]. In Voprosy iazykoznaniia, 5, 3-15.

Krapivin, V.P. (2006). Ryzhee znamia upriamstva [Red banner of stubbornness]. Moscow. 640 p.

Leech, G. (1983). Principles of Pragmatics. London. New York.

Osetrova, E. (2015). Being an Ethical Speaker Online: Correspondence with Foreign Partners. In Journal of Siberian Federal University. Humanities \& Social Sciences, 8 (11), 2561-2571. DOI: 10.17516/19971370-2015-8-11-2561-2571.

Osetrova, E.V., Zhang, Bo. (2015). Russian-language Internet correspondence with foreign students: rules of speech behaviour [Russkoiazychnaia internet-perepiska s uchastiem studentov-inostrantsev: pravila rechevogo povedeniia]. In Russkii iazyk i literatura v prostranstve mirovoi kul'tury: materialy XIII Kongressa MAPRYAL (g. Granada, Ispaniya, 13-20 sentiabria 2015 g.) [Russian language and literature in the space of the world culture: proceedings of the 13 $3^{\text {th }}$ Congress MAPRYAL (Granada, Spain. September 13-20, 2015)], 13, 41-44.

Osokina, S.A. (2018). «Svoe» i «chuzhoe» v detskoi rechi [“Own” and "foreign” in children's speech]. In Vestnik

Tomskogo gosudarstvennogo universiteta. Filologiya [Bulletin of Tomsk State University. Philology], 55, 88-105.

$$
-1925-
$$


Rozhdestvenskii, Iu.V. (1979). Vvedenie v obshchuiu filologiiu [Introduction to General Philology]. Moscow. Vysshaia shkola. $224 \mathrm{p}$.

Shmeleva, T.V. (1983). Kodeks rechevogo povedeniia [Code of speech behavior]. In Russkii iazyk za rubezhom, 1, 72-77.

Speranskaia, A.N. (1999). Pravila rechevogo povedeniia v russkikh paremiiakh: avtoreferat dissertatsii na soiskanie uchenoi stepeni kandidata filologicheskikh nauk [The rules of verbal behaviour in the Russian Proverbs: PhD thesis]. Krasnoyarsk. 210 p.

\section{Коммуникативная норма в неформальном русскоязычном общении: специфика детской речи}

\section{А.Б. Сильвестрова}

Красноярский государственный педагогический университет им. В.П. Астафьева Россия, 660049, Красноярск, ул. Ады Лебедевой, 89

Статья посвящена анализу коммуникативной нормы и отклонений от нее в неформальном русскоязычном общении на материале детской речи, в частности исследованию правил речевого поведения в интересах слушающего и реализации этикетных жанров в детском, детско-родительском и подростковом диалоге. На материале аутентичных детских высказываний, зафиксированных на красноярском форуме «Krasmama», и текстов современной русской литературы для детей проведен анализ правил речевого поведения как параметров коммуникативной ситуации. Рассмотрен механизм коммуникативных ошибок, реконструированы коммуникативные сценарии соблюдения и нарушения правил речевого поведения. Особое внимание уделено этикетным высказываниям, имеющим цель воздействия на адресата или манипуляции. В результате обнаружено, что для детской речи характерны неосознанные нарушения коммуникативных норм и, в частности, правил речевого поведения в интересах слушающего. Причиной ошибок может стать подражание взрослой неформальной, сниженной речи. С другой стороны, следование коммуникативной норме, а именно соблюдение правил речевого поведения и употребление этикетных речевых жанров в детско-родительской коммуникации, приводит к неоднозначным результатам и может свидетельствовать об осознанном намерении ребенка воздействовать на взрослого или манипулировать им. Этикетные высказывания в устах ребенка являются маркерами взрослой речи. В общении между детьми, а особенно между подростками, как показывает анализ текстов современной литературы для детей, неуместное соблюдение этикетных норм может сигнализировать о скрытых целях автора, еще неизвестных адресату (воздействие, манипуляция), либо о коммуникативной ошибке.

Ключевые слова: устная коммуникация, неформальная коммуникация, коммуникативная норма, коммуникативное нарушение, коммуникативная ошибка, правила речевого поведения, этикетные жанры, вежливость, детская речь.

Научная специальность: 10.02.01 - Русский язык. 